\title{
Adoption of goat husbandry practices by goat keepers in Amravati district
}

\author{
NEHA S. POTE, S. U. MOKHALE, N. O. KHANDARE AND S. A. KANSE
}

\begin{abstract}
The present study was conducted in Amravati district of Maharashtra state. The sample was drawn from the three takula viz., Chandur bazaar, Morshi, Chandur Railway where functional goat keepers in larger numbers were in existence. Thus, 80 goat keepers were selected which constituted the sample respondents for the present study. Data were collected by personally interviewing the respondents with the help of pre-tested structured interview schedule in face to face situation. Collected data were tabulated. Correlation and regression analysis for interpretation of the findings were calculated. Two hypotheses were set for the study and were tested for acceptance or rejection.Results obtained after analysis were summaries as below. In case of personal profile of the goat keepers revealed that majority $(58.75 \%)$ of the goat keepers were middle in age, over $(11.25 \%)$ were illiterate. Majority (66.25\%) of goat keepers belonged to medium family size (4 to 6 member) with majority of (56.25\%) nuclear family type. Majority (70.00\%) of the goat keepers had medium herd size (between 16 to 27 goats) having goat keeping + landless labour occupation (56.25\%) with annual income upto Rs. 50,000. Nearly half of the (42.05\%) of goat keepers had low social participation, moderate $(72.05 \%)$ access to the infrastructural facilities. The goat keepers in majority were found to be aware and adopting the practices of buck for natural service, Kachha or Packka type of housing, extensive method of rearing, feeding of leaves, colostrum feeding, goat insurance, but majority of them frequently adopt the practices of selection of descript breeds of goat, feeding of concentrates of milking goat and breeding buck. Results of the relational analysis revealed that age, education, family type, herd size, occupation, annual income, social participation and infrastructural facilities were significantly associated with adoption of goat keepers. However, except family size.
\end{abstract}

KEY WORDS : Adoption, Goat keeper, Technical knowledge, Goat rearing, Herd size, Recommended practices, Goat rearing

HOW TO CITE THIS PAPER : Pote, Neha S., Mokhale, S.U., Khandare, N.O. and Kanse, S.A. (2017). Adoption of goat husbandry practices by goat keepers in Amravati district. Res. J. Animal Hus. \& Dairy Sci., 8(2) : 90-93 : DOI: 10.15740/HAS/RJAHDS/8.2/90-93.

\footnotetext{
Address for correspondence :

S.U. Mokhale, Department of Extension Education, Shri Shivaji Agriculture College, AMRAVATI (M.S.) INDIA

Email : shekharmokhale17@gmail.com

Associated Authors':

Neha S. Pote, Department of Extension Education, Shri Shivaji Agriculture College, AMRAVATI (M.S.) INDIA

N.O. Khandare, Department of Animal Husbandry and Dairy Science, Shri Shivaji Agriculture College, AMRAVATI (M.S.) INDIA

S.A. Kanse, Department of Agronomy, Shri Shivaji Agriculture College, AMRAVATI (M.S.) INDIA
} 